\title{
MEMBACA TUBUH GUSTI AYU KADEK MURNIASIH: REPRESENTASI SEKS, KEKERASAN, DAN KUASA LAKI-LAKI
}

\author{
Hardiman $^{1}$, Luh Suartini ${ }^{2}$ \\ 1,2 Jurusan Pendidikan Seni Rupa, Fakultas Bahasa dan Seni \\ Universitas Pendidikan Ganesha \\ Singaraja, Indonesia \\ e-mail: hardiman art@yahoo.com,
}

\begin{abstract}
Abstrak
Penelitian ini bertujuan untuk mengungkapkan dan mendeskripsikan bentuk dan fungsi subject matter tubuh Gusti Ayu Kadek Murniasih dalam karya lukisannya; untuk mengungkapkan dan mendeskripsikan pula makna representasi seks, kekerasan, dan kuasa laki-laki dalam lukisan karya Gusti Ayu Kadek Murniasih. Penelitian kualitatif dengan pendekatan cultural studies ini, sebagaimana yang diringkus oleh teori-teori kritis, terutama diharapkan menghasilkan pembacaan konteks dengan tetap tidak mengabaikan pembacaan teks (visual). Penelitian ini memperoleh hasil: (1) Bentuk dan fungsi lukisan I Gusti Ayu Kadek Murniasih adalah turunan dari gaya Pengosekan. Ini ditandai dengan penggunaan kontur yang tegas sebagai pembagi unit-unit objek, bentuk berjejer dan repetisi, yang secara konviguratif menghasilkan susunan ornamen yang dekoratif. Murni menemukan idioleknya sendiri yang khas. (2) Tema lukisan Murni adalah persoalan seksual yang didorong oleh realitas biografinya yang mengalami peristiwa kekerasan fisik terhadap tubuhnya. Sebuah laku kekerasan yang memosisikan perempuan sebagai objek seksual bagi laki-laki.
\end{abstract}

Kata kunci: kekerasan, seks, tubuh

\begin{abstract}
This study aims to reveal and describe the form and function of the body's subject matter of Gusti Ayu Kadek Murniasih in her paintings: to disclose and describe the meaning sex representation, violence, and power of men in paintings by Gusti Ayu Kadek Murniasih. Qualitative research with cultural studies approach are used in this study. As arrested by the critical theories, this researt is expected to produce eadings wath not ignoring the context of the reading text (visual). The results obtained by the research are: (1) The form and function of the paintings I Gusti Ayu Kadek Murniasih is derived from Pengosekan style. It is characterized by the use of contour firmly on the shared object units, lined shape and repetition, which konviguratif produce a decorative ornament arrangement. Pure finding themselves idioleknya typical. (2) Pure painting theme is sexual problems driven by the reality of her biography, an incident of physical violence against her. A violent behavior that position women as sexual objects for men.
\end{abstract}

Keywords: violence, sex, body

\section{PENDAHULUAN}

Anak keluarga petani dari Tabanan, Bali ini, bernama lengkap I Gusti Ayu Kadek Murniasih (lihat gambar 1). Lahir pada 21 Mei 1966. Suatu hari ia harus ikut ayahnya bertransmigrasi ke Sulawesi. Tentu saja, harapan yang muncul di benaknya: ingin memperbaiki tarap hidupnya. Namun di daerah transmigrasi itu, tanda-tanda kehidupan yang lebih baik tidak muncul juga. Kemudian ia memilih bekerja sebagai pembantu rumah tangga di keluarga Cina, di Ujung Pandang. Sambil menjadi pembantu rumah tangga, beruntung, ia disekolahkan majikannya di sebuah SMP. Hanya sampai kelas dua, keluarga Cina itu keburu pindah ke Jakarta. Murni juga diajak serta. Di Jakarta ia tidak bersekolah, tetapi bekerja 
sebagai tukang jahit di perusahaan garmen milik majikannya itu. Tak lama ia di Jakarta, tahun 1987 memilih kembali ke Bali. Di tanah kelahiranya ini, ia sempat bekerja sebagai pembuat perhiasan perak di sebuah perusahaan perak di Celuk, Gianyar. Di sini ia ketemu jodohnya, menikah. Rumah tinggal yang juga merangkap studionya terletak di tengah-tengah kebun. Di rimbunnya berbagai jenis pepohonan dengan sebagian tanaman yang dibiarkan tumbuh damai, rumah-studio Murni terasa sejuk. Di rumah-studio dengan lantai bata dan semen ini ia terus berkarya, menggubah lukisan sebagai pernyataan diri atas ketidakadilan gender. Tak henti-henti, ia terus mempersoalkan tubuh dalam lukisannya.

$\begin{array}{lll}\text { Melalui } & \text { ribuan lukisan yang } \\ \text { digubahnya, } & \text { Murni } & \text { menghadirkan }\end{array}$ eksistensinya sebagai perempuan perupa. Eksistensi yang dilandasi oleh konsep penggubahan dengan latar biografi yang pedih. Tubuh dalam lukisan Murni menjadi representasi biografinya. Melalui tubuh itu juga, Murni memainkan wilayah representasinya melalui cara menghubungkaitkan dengan obyek kasur, tikar, meja makan, topi, sepatu, kuas, topeng, bawang, ikan, cicak, bahkan pisau dan gergaji. Obyek-obyek yang melingkupi tubuh, khususnya pada vagina dalam karyanya itu dibangun untuk keleluasaan representasi sekitar biografinya.

Persoalan rumah tangga. Persoalan lakiperempuan. Persoalan alat reproduksi. Persoalan genital. Persoalan-persoalan itulah yang membekas dalam biografinya. Betapa tidak, semasa remaja Murni pernah digagahi laki-laki dewasa. Sebuah peristiwa yang membekas menjadi luka abadi. Luka ini diperparah pula dengan peristiwa perceraian dengan suaminya. Persoalan reproduksi, karena Murni secara biologis tidak bisa melahirkan. Tubuh baginya

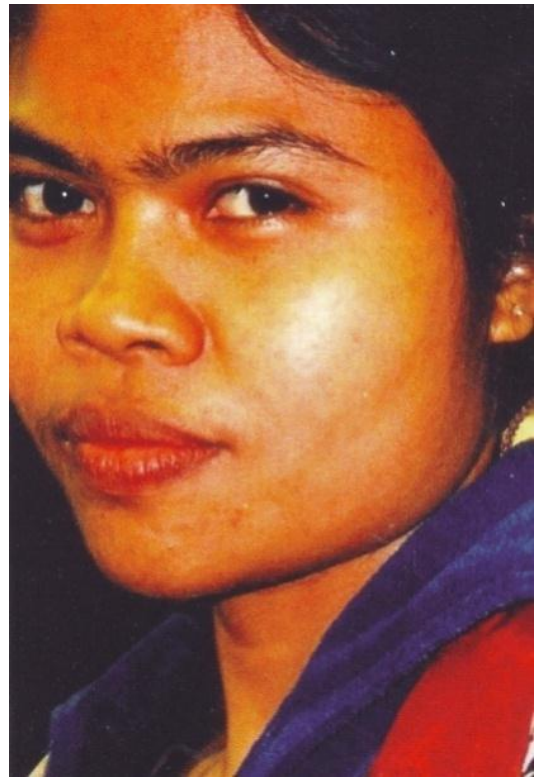

Gambar 1. I Gusti Ayu Kadek Murniasih

(Sumber: Visual Arts, Jakarta)

adalah penderitaan. Hal-hal itulah yang kemudian muncul menjadi motivasi atau konsep dalam lukisannya.

Murni sejak 1995 sudah merepresentasikan tubuhnya ke dalam karya seni rupa. Karya-karya Murni hadir dalam berbagai perhelatan seni rupa, baik di tingkat Nasional maupun regional dan internasional. Persoalan yang dikemukakan Murni adalah persoalan tubuh yang teralami.

Apa-apa yang direpresentasikan oleh seniman, senantiasa dipengaruhi oleh keadaan diri sang seniman itu sendiri. Dalam hal ini, biografi, visi kesenian, ideologi, lingkungan sosial-budaya, dan lainlain memengaruhi pilihan dan cara merepresentasikannya. Oleh karena itulah, kesenian, secara umum, tidak dapat sepenuhnya dipahami tanpa menempatkannya dalam keseluruhan kerangka masyarakat dan kebudayaan. Hubungan timbal balik inilah yang melahirkan pendapat bahwa karya seni yang baik adalah suara zaman. ${ }^{1}$

\footnotetext{
Pendapat ini dikemukanan kritikus seni rupa Indonesia, Sanento Yuliman. Lebih jauh
} 
Suara zaman atau sezaman secara eksplisit dalam sejarah seni rupa Indonesia misalnya, bahkan sejak zaman prasejarah, telah dengan tegas memerlihatkan hubungan seni rupa dengan fenomena masyarakat yang terjadi saat itu. Pada zaman prasejarah, lukisan dinding misalnya, bertalian dengan peradaban animisme dengan kepercayaan manusia masa itu terhadap dunia gaib (magis). Pada masa seni rupa modern Indonesia, karya seni rupa bertalian dengan perjuangan masyarakat dalam menentang penjajahan.

Dewasa ini, seni rupa kontemporer Indonesia muncul dalam kerangka yang kurang-lebih sama. Seni rupa kontemporer Indonesia hadir menyuarakan zaman kini yang kompleks dengan persolan kemanusiaan. Kapitalisme global yang tidak terbendung, perusakan lingkungan yang tidak terkendali, sain dan teknologi informasi yang demikian maju pesat, perang fisik dan perang ideologi yang makin menjadi, pribadi manusia yang terbelah, masalah perempuan dan gender yang terus mengemuka, seks dan kekuasaan yang makin menajam, dan lain-lain adalah contoh yang bisa disebut sebagai gambaran peradaban manusia masa kini.

Perupa kontemporer Indonesia memiliki berbagai persoalan dalam proses pergulatan tersebut. Kebudayaan lokal, persolan psikologis, dan konteks lainnya adalah wilayah yang mengepung proses ini. Namun demikian, yang paling khas memiliki persolan ini adalah perempuan perupa Indonesia dengan persoalan tubuhnya. Perempuan masa kini yang memuliakan hak-hak tubuhnya sembari tetap terikat oleh hak-hak komunal atas (keber) tubuh(annya). Dalam kasus ini, Gusti Ayu Kadek Murniasih, perempuan Bali yang lahir dan dibesarkan dalam wilayah kultural Bali yang patriarkhi adalah contoh yang paling fenomenal. Tubuhnya bukan hanya memiliki

tentang ini, periksa Asikin Hasan, 2001. Dua Seni Rupa, Sepilihan Tulisan Sanento Yuliman, Jakarta: Kalam sejarah luka yang tajam menggores biografinya, tetapi juga punya riwayat perlawanan terhadap kuasa laki-laki. Gusti Ayu Kadek Murniasih adalah perempuan yang menyadari bahwa tubuhnya adalah asset yang amat berharga untuk digunakan sebagai perlawanan terhadap kuasa laki-laki yang patriarkhi.

Gusti Ayu Kadek Murniasih, seperti juga perempuan pada umumnya, berhadapan dengan konstruksi sosialbudaya yang kerap merugikan kaum perempuan. Inti semua ini, antara lain, bersumber dari persoalan seks yang dalam banyak kebudayaan di Indonesia menempatkan laki-laki sebagai subyek dan perempuan sebagai obyek seks. Inilah wilayah kuasa kerajaan laki-laki dan kebudayaan patriarkhi yang secara menerus digugat Gusti Ayu Kadek Murniasih.

Penelitian dengan tajuk "Membaca

Tubuh Gusti Ayu Kadek Murniasih: Representasi Seks, Kekerasan, dan Kuasa Laki-Laki" ini dengan subjek penelitian ini adalah tubuh Gusti Ayu Kadek Murniasih dalam karya lukisnya. Penelitian ini memilih perspektif cultural studies- dengan teori tandem: semiotika visual, teori estetika, teori feminisme, dan teori representasi.

Berdasarkan pemahaman di atas, maka ada dua pertanyaan penelitian agar kajian menjadi fokus. Pertanyaan penelitian tersebut bertalian dengan upaya membincangkan pembacaan ihwal: (1) Bagaimanakah bentuk dan fungsi tubuh Gusti Ayu Kadek Murniasih sebagai subject matter dalam lukisannya?; (2) Apakah makna representasi seks, kekerasan, dan kuasa laki-laki dalam lukisan karya Gusti Ayu Kadek Murniasih. 


\section{METODA PENELITIAN}

Penelitian kualitatif ini disiapkan dengan menyusun sejumlah langkah penelitian yang meliputi rancangan penelitian, penentuan lokasi penelitian, penentuan jenis dan sumber data, penentuan instrumen penelitian, penentuan teknik pengumpulan data, penentuan teknik analisis data, dan kemungkinan penyajian hasil analisis data.

Teknik pengumpulan data dilakuka melalui teknik observasi, wawancara, dan kepustakaan. Analisis data dilakukan dalam tiga tahapan, yaitu: open coding, axia coding, dan selective coding.

\section{HASIL DAN PEMBAHASAN BENTUK DAN FUNGSI}

Tiga unsur rupa tradisi yakni cawi, ngabur, dan ornamen dekoratif adalah kosa tradisi Bali yang telah menjadi dialek milik para perupa penggemong seni tradisi Bali. Sebagaimana makna dialek yang memiliki variasi bahasa yang berbeda-beda menurut pemakai, baik berada dalam satu daerah tertentu, kelompok sosial tertentu, maupun masa tertentu, unsur rupa tradisi Bali tersebut pada karya Murni berkembang menjadi idiolek. Hal ini bisa terlihat dari keseluruhan ciri perseorangan dalam bahasa rupanya.

Idiolek Murni misalnya, adalah turunan dari gurunya, I Dewa Putu Mokoh (selanjutnya disebut Mokoh). Mokoh adalah salah seorang pelukis penting di Bali. la dilahirkan di Pengosekan tahun 1963. Mokoh memulai kariernya sebagai pelukis ketika ia masih berusia belasan tahun, belajar melukis dari I Ketut Kobot (selanjutnya disebut Kobot). Sejak tahun 1970-an lukisan Mokoh berbeda dengan karya gurunya, Kobot. Pada tahun itu pula Mokoh bersama saudara kandungnya, I Dewa Nyoman Batuan (selanjutnya disebut Batuan) mendirikan sanggar kerja dan galeri yang diberi nama "Kelompok Seniman Pengosekan". Kelompok ini mulai mengenalkan tema-tema lukisan baru yang elok: lukisan bunga-bunga dan burung.
Gaya dan tema ini kerap dikaitkan dengan peran Mokoh dan Batuan.

Tahun 1989 Mokoh bertemu dengan Mondo, pelukis berkebangsaan Italian yang bermukim di Bali. Bersama Mondo, Mokoh melakukan kolaborasi dalam kanvas-kanvas yang sama. Satu kanvas ditandatangani berdua: Mondo/Mokoh. Karya-karya mereka pernah dipamerkan di Niennale Venesia, Italia, tahun 1993. Persentuhan dengan Mondo inilah yang kemudian melahirkan karya-karya baru yang khas. Figur-figur telanjang dari Barat menjadi stimulus Mokoh untuk melukiskannya dengan tafsir pribadi.

Murni selama lebih-kurang satu tahun belajar dari Mokoh. Murni belajar dasar-dasar melukis gaya Pengosekan. Mulai dari belajar membuat garis hingga belajar mewarnai. Selain itu, Murni juga melukis bersama dengan Mokoh dan Mondo di teras rumnah Mondo di Ubud. Proses melukis bersama itu memberi pengaruh yang kuat terhadap gaya dan tema lukisan Murni. Mokoh dan Mondo adalah dua figur yang memberi peran penting bagi pertumbuhan kesenirupaan Murni hingga Murni benar-benar menemukan gaya seni lukisnya yang pribadi.

Gaya ini adalah turunan dari Mokoh yang perintis gaya Pengosekan itu. Secara kebentukan, lukisan Murni adalah turunan dari gaya Pengosekan. Ini ditandai dengan penggunaan kontur yang tegas sebagai pembagi unit-unit objek, bentuk berjejer dan repetisi, yang secara konviguratif menghasilkan susunan ornamen yang dekoratif. Kendatipun Murni dengan sadar menggunakan dialek rupa Pengosekanyang adalah milik kolektif masayarakat pelukis Pengosekan ia berhasil menemukan idioleknnya sendiri. Idiolek ini dengan mudah bisa terbaca dari visualisasinya yang khas Murni: garis tegas dan tebal, warna monokrome, kontras, atau komplimenter, dan repetisi dalam interval yang hening. Hal ini diperlihatkan melalui ciri rupa turunan dengan penggunaan teknik nyawi (lihat gambar 2), teknik ngabur (lihat gambar 3), penggunaan ornamen dekoratif (lihat 
gambar 4), dan kecenderungan memakai

objek tunggal dalam lukisannya.

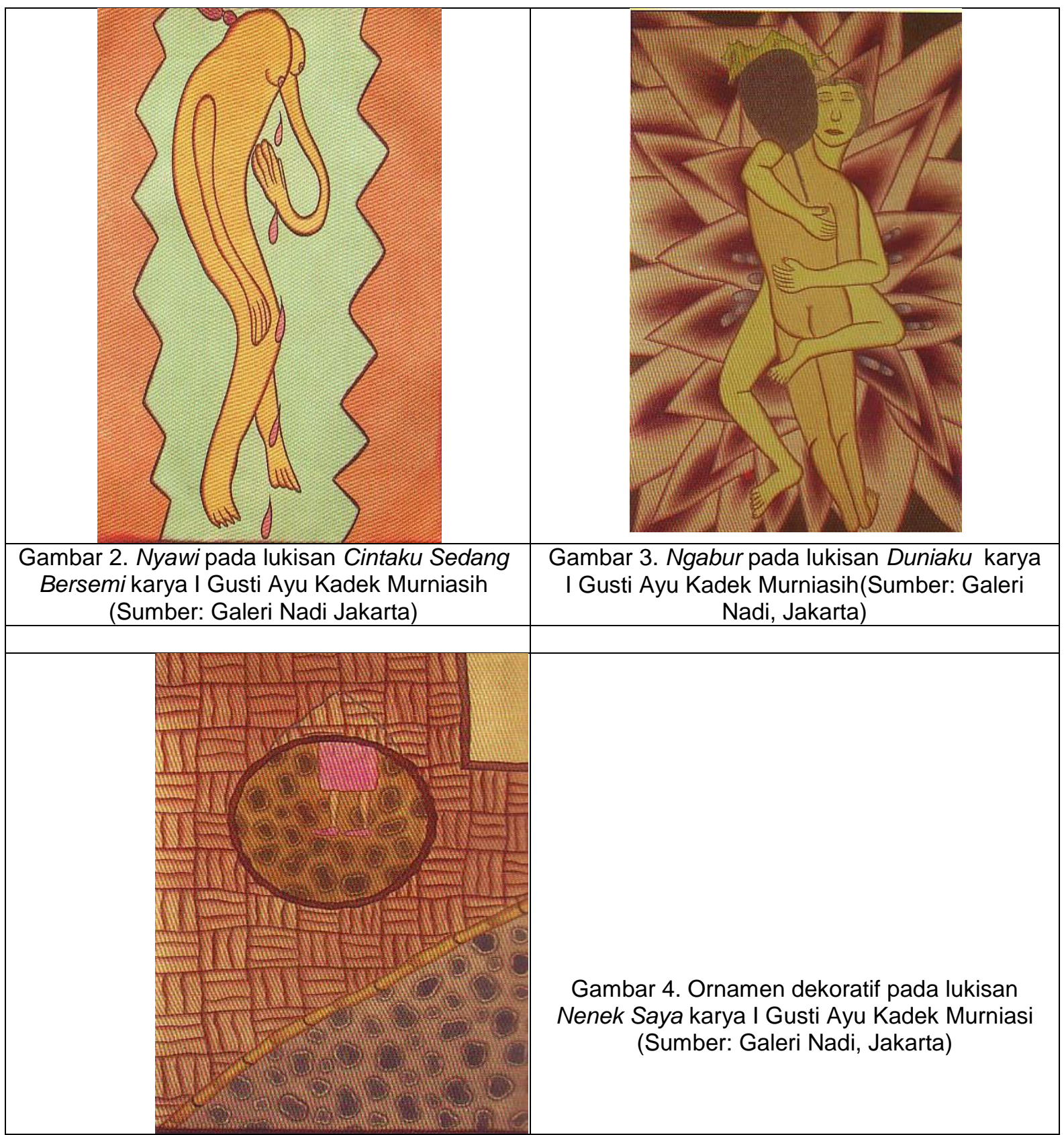


Perempuan perupa ini adalah penjaga tradisi rupa Bali yang dengan kepekaan dan daya gubahnya telah melahirkan idioleknya tersendiri. Secara konviguratif, dialek rupa tradisi pada karya Murni masih bisa terbaca dengan jelas. Di sisi lain, idioleknya juga tampak dengan tegas. Perempuan perupa ini adalah perupa Bali yang memiliki kesadaran kosmologisnya. Sebuah wilayah budaya yang ikut dibangunnya.

\section{MAKNA}

Jauh sebelum dunia sastra Indonesia dihebohkan oleh kemunculan perempuan muda pesastra yang menggarap persoalan seks dan seksualitas ke dalam karya-karya fiksinya, ${ }^{2}$ I Gusti Ayu Kadek Murniasih sejak 1995 sudah mengeksplorasi tubuhnya ke dalam karya seni rupa. Kendatipun karyakarya seni rupa Murni tidak mendapat perhatian atau pembahasan sedalam dan seheboh sastrawangi, tetapi karya-karya Murni hadir dalam berbagai perhelatan seni rupa, baik di tingkat Nasional maupun dalam biennal-biennal regional dan internasional.

Salah satu karyanya yang dipamerkan dalam CP Open Biennale-sebuah perhelatan internasional di Jakarta-tahun 2003 adalah Pohon Kesukaanku (akrilik di atas kanvas, $160 \times 100 \mathrm{~cm}$, tahun 2003).

2 Kemunculan perempuan muda penulis sastra yang mengangkat persoalan seksualitas dimulai oleh kehadiran Saman karya Ayu Utami. Saman adalah fragmen dari novel pertama Ayu Utami, Laila Tak Mampir di New York. Fragmen ini memenangkan Sayembara Roman Dewam Kesenian Jakarta tahun 1998. Setelah Ayu Utami kemudian muncul namanama lain yang oleh sejumlah pengamat sastra, dunia sastra perempuan muda pesastra ini disebut sebagai "Sastrawangi". Penamaan ini terkait dengan tampilan mereka yang cantik, menarik, dan senantiasa harum. Tetapi, yang jauh lebih penting dari penamaan itu adalah munculnya berbagai tanggapan terhadap persoalan seksualitas dalam karya mereka. Sejumlah pengamat terlibat dalam berbagai polemik di media massa.
Lukisan ini digubah dengan pembentukan batang pohon yang secara struktur memalih ${ }^{3}$ menjadi bentuk penis. Pohon penis ini memiliki tujuh buah cabang yang tumbuh ke semua sisi. Pohon penis ini diberi warna putih bersih dengan kontur rapi berwarna merah.

Di bagian bawah pohon ada bentuk tak beraturan yang amat menyerupai bentuk vagina. Bentuk ini diberi warna biru tua dengan sekumpulan arsir garis tak beraturan yang mengelilingi bagian luarnya. Di latar belakang ada pola garis setengah lingkaran yang disusun berulang memenuhi seluruh bagian bidang latar belakang. (Lihat Gambar 5) Ada beberapa makna yang bisa diproduksi dari lukisan ini. Pertama, penis dan vagina dengan pilihan warna serta bentuk seperti lukisan di atas adalah sebuah konstruksi sosial yang membedakan kedudukan penis dan vagina sebagai sesuatu yang amat berbeda. Kedua, hal ini terkait juga dengan perbedaan gender yang melahirkan subordinasi dan ketergantungan. Penggambaran penis dan vagina seperti ini terkait dengan anggapan bahwa kelamin laki-laki kerap dinilai sebagai benda yang kering yang langsung terkonotasikan dengan bersih. Dalam lukisan ini penis digambarkan dalam bentuk yang rapi, putih,

3 Malih adalah sinonim dari berubah rupa. Bentuk-bentuk yang memalih banyak ditemukan dalam khasanah seni rupa tradisional. Batik motif parang rusak misalnya, secara struktur bentuk parangnya sudah tidak bisa dikenali lagi. Bentuk parang dalam motif parang rusak, dengan demikian, telah memalih menjadi sebuah motif hias geometis yang stilistik. Contok lain penggunaan kata "malih" ini, misalnya dalam kepercayaan tertentu, orang yang melakukan pesugihan diyakini tubuh biologisnya akan memalih menjadi tubuh babi. Istilah "memalih" dipopulerkan oleh Prof. Dr. Sudjoko, guru besar Seni Rupa ITB. Tentang penggunaan istilah "malih", "memalih", dan "palihan" lihat Sudjoko, "Menuju Nirada", dalam Baranul Anas (ed.). 2000. Refleksi Seni Rupa Indonesia. Jakarta: Balai Pustaka.

Jurnal IImu Sosial dan Humaniora | 192 
dan jelas strukturnya. Murni, tadak bisa tidak, telah mengamini anggapan umum tentang penis.

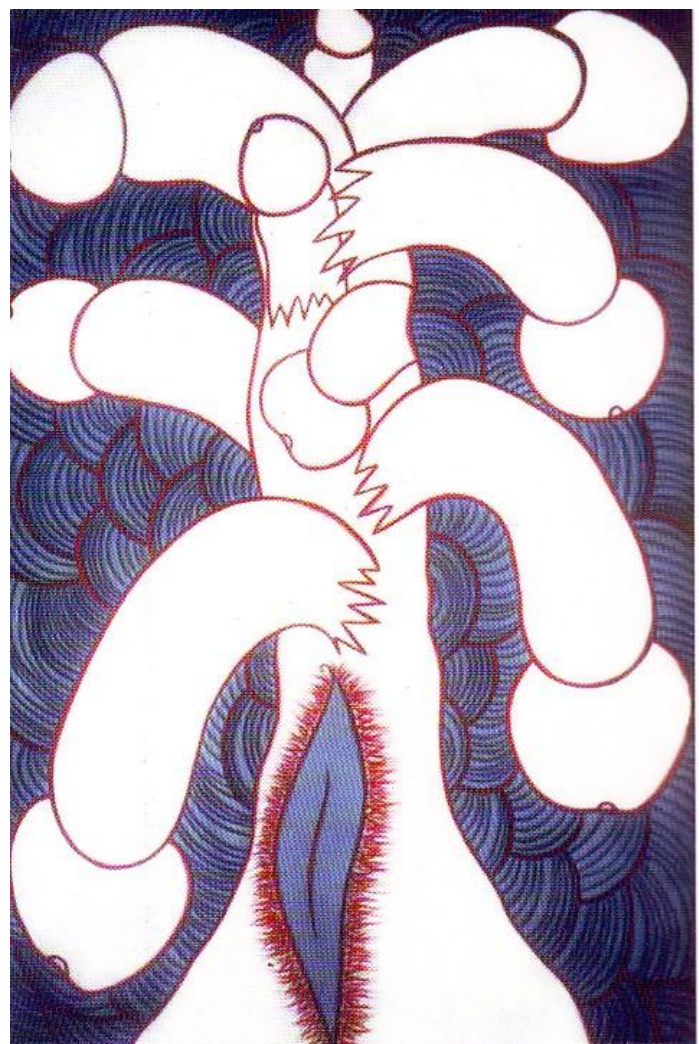

Gambar 5. Pohon Kesukaanku karya I Gusti Ayu Kadek Murniasih

Sumber: CP Open Biennale 2003, Jakarta

Sejalan dengan itu, ketika Murni menggambarkan vagina eksekusi visual yang dipilinnya adalah hadirnya bentuk vagina yang strukturnya atertib atau tidak beraturan. Pilihan warna yang dipakainya juga makin menegaskan ketidakberaturan itu. Biru tua dengan sedikit nuansa hitam adalah warna yang mencitrakan kotor. Penggambaran vagina dengan warna biru tua ini terkait dengan anggapan bahwa vagina dicitrakan sebagai sesuatu yang kotor, basah, dan berdarah. Kesan ini dipertegas pula dengan sekumpulan arsir garis yang mengitari kontur vagina dengan warna merah tua yang mencitrakan ketidaksegaran.

Kendatipun melalui lukisan ini Murni tampak mengamini realitas konstruksi sosial-budaya itu, tetapi ada makna lain yang secara semiotis menggambarkan perbedaan gender yang melahirkan subordinasi dan ketidak adilan. Pencitraan penis sebagai sesuatu yang jelas bentuknya, kering, dan bersih; di sisi lain pencitraan vagina yang tidak jelas bentuknya, basah, dan kotor, tentu saja merugikan kaum perempuan.

Dalam lukisan Murni, secara estetis, makna bisa juga diproduksi melalui cara penggubahannya. Penempatan vagina menempel pada bagian bawah penis seolah menggambarkan bahwa vagina hanyalah "bagian" dari penis. Hal ini terhubung pula dengan subordinasi perempuan atas lakilaki. Ini terkait pula dengan asal-usul Hawa yang bersumber dari tulang rusuk Adam yang merupakan pembenaran status inferior perempuan. Secara konotatif, ada kesan bahwa vagina adalah sesuatu yang daya (ke)hidup(an)-nya terletak pada daya (ke)hidup(an)-nya penis.

Subordinasi ini berkorespondensi juga dengan ketergantungan. Ketergantungan adalah salah satu bentuk kekerasan terhadap perempuan. Perempuan, dalam lukisan ini diwakili oleh vagina, seperti tidak memiliki ruangnya selain pada penis. Judul lukisan ini saja, Pohon Kesukaanku, dengan jelas menegaskan penis (malihan dari pohon) sebagai objek utama; dan menempatkan vagina sebagai objek pelengkap. Sebuah subordinasi yang menegaskan ketergantungan itu.

Eksekusi visual yang dilakukan Murni dengan cara yang terbuka dan amat verbal, sepintas seolah hanya mendobrak tabu seksualitas. Sesungguhnya makna yang terkandung dari lukisan ini lebih jauh daripada sekadar mendobrak tabu. Lukisannya lebih bisa diapresiasi sebagai semangat menggugat budaya patriaki. Hal ini memiliki korespondensi dengan latar 
biografinya yang memperlihatkan Murni sebagai yang terpinggirkan. Ketika Murni masih belia, usia tujuh tahun, ia mengalami peristiwa yang amat membuat ia pedih: digagahi laki-laki dewasa. Peristiwa mengerikan itu hingga ia menjelang wafat terus membayangi pikiran dan perasaannya. Murni tergores, amat luka.

$$
\text { Serupa lukisan di atas, }
$$

Ketergantunganku (2004) melukiskan posisi perempuan yang tersubordinasi atas lakilaki. Lukisan ini dibangun oleh susunan dua pokok gambar: perempuan telanjang terikat pada sebuah penis yang besar. Secara semiotis lukisan bisa memproduksi berbagai makna. Ukuran penis yang melampaui ukuran tubuh perempuan bisa bermakna bahwa penis dalam hal ini lebih penting. Sesuatu yang superior. Dengan sendirinya tubuh perempuan adalah sesuatu yang inferior. la (tubuh perempuan) menjadi amat kecil atau tak berdaya dihadapan penis. (Lihat Gambar 6)

Makna lain yang bisa diproduksi dari lukisan ini adalah makna subordinasi dan ketergantungan perempuan atas laki-laki. Tubuh perempuan adalah wilayah tempat tumpah-ruahnya kuasa, hegemoni, dan dominasi laki-laki. Korespondensi yang bisa ditarik dari lukisan ini adalah kriteria eksternal di mana biografi Murni yang sejak masa kanak-kanak telah dihancurkan oleh laki-laki; kehidupan rumahtangganya yang bukan hanya tak utuh, tetapi juga menyakitkan. Selain itu dalam sejumlah lukisan Murni kerap ditemukan tubuh telanjang yang disandingkan dengan bendabenda: pisau, bawang, meja makan, gergaji, kikir, dan lain-lain. Ada kesan bahwa tubuh telanjang itu adalah gambaran tentang dirinya, perempuan yang berhadapan dengan berbagai kekerasan seksual. Betapa tidak, genital dalam lukisan Murni misalnya, kerap digambarkan sebagai genital yang robek, luka, menganga, atau tak berdaya. Di sekitar genital itu objek-objek tajam bertebaran. Tubuh perempuan dalam lukisan-lukisan ini terpenjara oleh hasrat dan kuasa laki-laki.

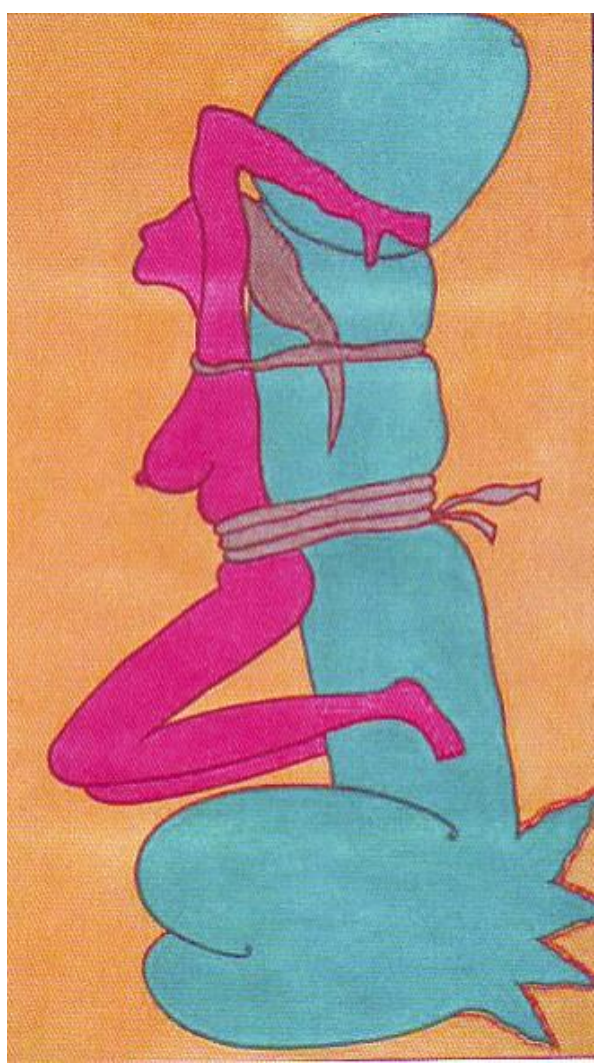

Gambar 6. Ketergantunganku karya I Gusti Ayu Kadek Murniasih

Sumber: Galeri Nava, Denpasar

Sejumlah lukisan yang memperlihatkan hal ini, antara lain Action (akrilik di atas kanvas, $50 \times 35 \mathrm{~cm}$, tahun 1996) yang memperlihatkan seorang perempuan bertelanjang dalam posisi menungging di atas meja sedang bersetubuh dengan mahluk aneh yang menyerupai reptilia. Mahluk aneh itu ukuran tubuhnya sekitar empat kali lipat tubuh perempuan. Ada kesan yang segera dapat ditangkap dari lukisan ini: tubuh perempuan serupa objek "santapan" bagi mahluk yang menyerupai struktur tubuh reptilia itu. Reptilia yang carnivora atau pemakan daging ini, secara semiotis bisa memproduksi makna konotatif: reptilia bisa disimbolkan sebagai laki-laki. Sebuah 
pelukisan narasi simbolik yang menegaskan posisi perempuan sebagai objek.

Lebih jauh dari itu, Trauma 2 (akrilik di atas kanvas, $50 \times 50 \mathrm{~cm}$, tahun 1998), memperlihatkan tubuh perempuan sebagai objek kekerasan seksual. Lukisan ini dibangun oleh sebagian tubuh perempuan: pinggang, pantat, dan paha. Dalam balutan warna biru pucat, tubuh dalam posisi menungging itu, bagian belakangnya tampak sedang disentuh atau ditusuk sebuah benda tajam. Dari strukturnya, benda tajam itu amat menyerupai alat pertukangan, kikir. Di latar belakang, sekumpulan garis dalam pola pancaran $^{4}$ tampak berpusat dari bagian tengah tubuh perempuan itu.

Dapat dibaca bahwa lukisan ini tidak lain adalah gambaran tentang kekerasan terhadap tubuh perempuan. Dalam konteks Murni, kekerasan itu berkorespondensi dengan latar biografinya yang memang mengalami dua kali kekerasan seksual. Tubuh perempuan dengan warna biru pucat seperti menegaskan bahwa tubuh perempuan dalam situasi mental ketakutan. Kikir bisa dibaca sebagai simbol atas laku kekerasan itu. Alat pertukangan yang konturnya bergerigi itu-biasanya dipergunakan untuk menghaluskan permukaan benda (kayu atau logam)segera terhubung dengan kekerasan. Latar belakang dengan pola pancaran makin menegaskan bahwa pusat kekerasan itu ditujukan pada kelamin perempuan. Genital

4 Dalam terminologi desain dwi matra, pancaran adalah jenis perulangan. Gatra yang berulang atau pangsa racana yang bergerak dengan teratur mengitari sebuah pusat. Pancaran dapat memberi kesan getaran lihatan, yang ditemukan pada perulangan. Ciri pancaran adalah mempunyai pumpunan yang kuat yang biasanya terletak pada pusat rancangan, dan dapat menimbulkan energi dan gerakan lihatan dari pusat atau menuju pusat. (Lihat Wicius Wong, 1995:45) atau vagina adalah ruang tempat tumpahruahnya kekerasan. (Lihat Gambar 7).

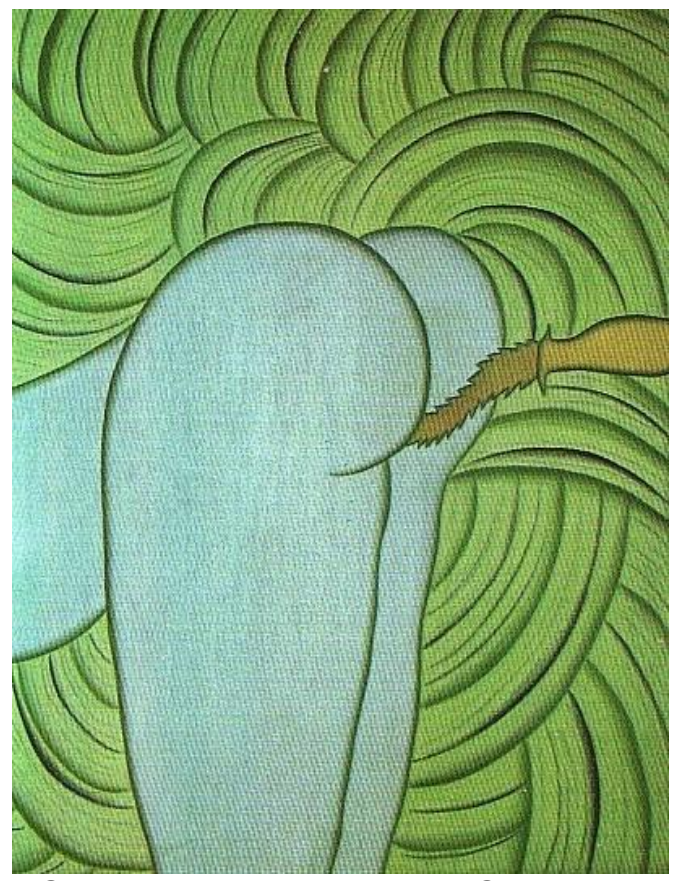

Gambar 7. Trauma 2 karya I Gusti Ayu Kadek Murniasih

Sumber: Galeri Nadi, Jakarta

Murni sejak 1995 secara terusmenerus menggali tema seputar persoalan seksual. Tema ini didorong oleh realitas biografinya yang mengalami peristiwa kekerasan fisik terhadap tubuhnya: perkosaan dan perceraian. Sebuah laku kekerasan yang memposisikan perempuan sebagai objek seksual bagi laki-laki. Perbedaan gender dan kuasa laki-laki yang menimbulkan kekerasan terhadap perempuan ini telah direpresentasikan oleh Murni dalam lukisan-lukisannya.

\section{SIMPULAN DAN SARAN}

Penelitian ini memperoleh hasil: (1) Bentuk dan fungsi lukisan I Gusti Ayu Kadek Murniasih adalah turunan dari gaya Pengosekan. Ini ditandai dengan penggunaan kontur yang tegas sebagai pembagi unit-unit objek, bentuk berjejer dan repetisi, yang secara konviguratif 
menghasilkan susunan ornamen yang dekoratif. Murni menemukan idioleknya sendiri yang khas. (2) Tema lukisan Murni adalah persoalan seksual yang didorong oleh realitas biografinya yang mengalami peristiwa kekerasan fisik terhadap tubuhnya. Sebuah laku kekerasan yang memosisikan perempuan sebagai objek seksual bagi lakilaki.

Saran disampaikan kepada peneliti lain yang akan melakukan penelitian sejenis terhadap karya I Gusti Ayu Kadek Murniasih disarankan untuk menkaji karya-karya tiga dimensinya yang jarang dibincangkan.

\section{DAFTAR PUSTAKA}

Barker, Chris. 2004. Cultural Studies, Teori \& Praktik (Alih Bahasa: Nurhadi). Yogyakarta: Kreasi Wacana.

Bianpoen, Carla dan Mella Jaarsma. 1996."Perempuan Perupa: Antara Visi dan Ilusi" dalam Mayling OeyGaediner (ed.), Perempuan Indonesia: Dulu dan Kini. Jakarta: Gramedia

Endraswara, Suwardi. 2003. Metodologi Penelitian Kebudayaan, Yogyakarta: Gadjah Mada University Press.

Fischer, Joseph. 1990. Modern Indonesian Art: Three Generation of Tradition and Change 1945-1990. Jakarta and New York: Panitia Pameran KIAS and Festival of Indonesia.

Piliang, Yasraf Amir. 2006, "Antara Homogenitas dan Heterogenitas: Estetika dalam Cultural Studies" (makalah). Denpasar: Kajian Budaya Universitas Udayana.

Spanjaard, Helena, 2004. Exploring Modern Indonesian Art. Singapura: SNP Editions.

Sudikan, Setya Yuwana. 2001. Metode Penelitian Kebudayaan. Surabaya: Citra Wacana.
Sumiarni, Endang. 2004. Jender \& Feminisme. Yogyakarta: WPC

Supangkat, Jim. 1999 "Seni Rupa Kontemporer Indonesia" (makalah) Denpasar: Edwin Gallery.

Supriyanto, Enin, 2007. Indonesian Contemporary Art Now, 2007, Singapura: SNP

Editions.

Synnott, Anthony. 1993. The Body Social, Symbolism, Self, and Society, (Tubuh Sosial, Simbolisme, Diri, dan Masyarakat). (Terjemahan: Yudi Santoso, 2003), Yogyakarta: Jalasutra.

Wardani, Farah. 2003. "Perempuan sebagai Teks (Dekonstruksi Jender dan Teks dalam Praktik Seni Rupa)", Harian KOMPAS, 5 September.

Wardani, Farah dan Eddy Soetriyono. 2004. "Dari Objek Menjadi Subjek, Perempuan dalam Seni Rupa Indonesia," dalam Visual Arts, No. 3, Oktober-November.

Wright, Astri. 1994. Soul, Spirit, and Mountain: Preoccupations of Contemporary Indonesian Paiters. Kuala Lumpur: Oxford University Press.

Hardiman, 2004. "Representasi Politik, Politik Representasi dalam Seni Rupa Kontemporer Indonesia" dalam Jurnal Kajian Budaya, No. 01, Vol.5, Januari. Denpasar: Kajian Budaya, Unud.

Hardiman dan Luh Suartini, 2011. "Eksistensi Sanggar Seniwati Bali: Perlawanan terhadap Dominasi lakiLaki Perupa dalam Medan Sosial Seni Rupa di Indonesia: dalam Jurnal Penelitian dan Pengembangan Sain dan Humaniora (JPPSH), Universitas Pendidikan Ganesha, Volume 5 Nomor 3, Desember.

Jurnal IImu Sosial dan Humaniora | 196 
Parta, I Wayan Seriyoga, 2010. "Tranformasi Seni Tiga Dimensional Bali" dalam Jurnal Prasi, No. 11, Vol.6, JanuariJuni. Singaraja: FBS Undiksha.

Hardiman, 2007. "Tubuh Perempuan: Representasi Gender Perempuan Perupa Bali" (tesis). Denpasar: Kajian Budaya, Universitas Udayana

Hardiman, 2007. "Subject Matter Tubuh Perempuan: Representasi Gender Perempuan Perupa Bali" (hasil penelitian Kajian Wanita) Jakarta: Dikti.

Hardiman, 2008. "Tubuh
Representasi Seks $\begin{aligned} & \text { Perempuan: } \\ & \text { Perupa Kontemporer Indonesia" } \\ & \text { (hasil penelitian fundamental). } \\ & \text { Jakarta: Dikti. }\end{aligned}$

